\title{
ETNOGRAFI: TRADISI PINDAH MARGA DALAM PERNIKAHAN DI NEGERI BUANO HATUPUTIH KECAMATAN KEPULAUAN MANIPA KABUPATEN SERAM BAGIAN BARAT
}

\author{
Amina Lausepa ${ }^{1}$, Sammad Umarella ${ }^{2}$, Mokhsin Kaliky ${ }^{3}$ \\ Program Studi Pendidikan Agama Islam FITK IAIN Ambon \\ email: \\ Lausepa14@gmail.com
}

\begin{abstract}
The purpose of this study is to explain the implementation of clan switching in the marriage customs of the people of Buano Hatuputih in Buano Hatuputih Country, Manipa Islands District, West Seram Regency. And to explain its meaning in the wedding customs of the people of Buano Hatuputih, Manipa Islands District, West Seram Regency. The type of research used is descriptive qualitative with the type of field research (field research) with the research time being carried out for one month starting from December 19, 2019 to January 19, 2020. The techniques used in this study include; observation, interviews and documentation and data analysis used is a descriptive analysis technique which is intended to describe the reality that occurs in the field. The results show that the tradition of changing clans in marriage in Buano Hatuputih Village, Manipa Islands District, West Seram Regency is a guide that gives direction and orientation to people's lives in this case is the people (male) of the Buton tribe who married people from Buano. Hatuputih in the form of rules for special actions, while the marriage process is general as regulated in Islamic law which is carried out in Buano Hatuputih Village. The meaning of marriage symbols in the customs of the people of Buano Hatuputih, Manipa Islands District, West Seram Regency, such as betel holders, rings, earrings, necklaces (gold), beauty tools (makeup), white cloth, a set of prayer tools, and a bed (mattress). and equipment) in a wedding in Buano Hatuputih Village reflects a good thing that must be done and or carried out by both men and women after the marriage is completed, because the essence of marriage is to remind each other of good relations to Allah swt and to others. man.
\end{abstract}

Keywords: Tradition of Changing Clans, Marriage, Buano Hatuputih

\begin{abstract}
Abstrak: Tujuan dari penelitian adalah untuk menjelaskan pelaksanaan pindah marga dalam adat pernikahan masyarakat Negeri Buano Hatuputih di Negeri Buano Hatuputih Kecamatan Kepulauan Manipa Kabupaten Seram Bagian Barat. Dan untuk menjelaskan maknanya dalam adat pernikahan masyarakat Negeri Buano Hatuputih Kecamatan Kepulauan Manipa Kabupaten Seram Bagian Barat. Jenis penelitian ini yang digunkaan adalah deskriptif kualitatif dengan tipe penelitian lapangan (field reseach) dengan waktu penelitian dilakukan selama satu bulan terhitung mulai dari tanggal 19 Desember 2019 sampai dengan 19 Januari 2020. Adapun tehnik yang digunakan dalam penelitian ini antara lain; observasi, wawancara dan dokumentasi dan analisis data yang digunakan yakni teknik analisis deskriptif yang dimaksudkan untuk menggambarkan realitas yang terjadi di lapangan. Hasil penelitian menunjukkan bahwa Tradisi pindah marga dalam pernikahan di Desa Buano Hatuputih Kecamatan Kepulauan Manipa Kabupaten Seram Bagian Barat merupakan sebagai pedoman yang memberi arah dan orientasi terhadap hidup masyarakat dalam hal ini adlaah masyarakat (laki-laki) suku Buton yang menikah dengan masyarakat dari Negeri Buano Hatuputih berupa aturan-aturan untuk bertindak bersifat khusus, sedangkan proses penikahannya bersifat umum sebagaiman diatur dalam syariat Islam yang dilaksanakan di Desa Buano Hatuputih. Pemaknaan simbol pernikahan dalam adat masyarakat Negeri Buano Hatuputih Kecamatan Kepulauan Manipa Kabupaten Seram Bagian Barat seperti tempat sirih, cincin, anting, kalung (emas), alat-alat kecantikan (make up), kain putih, seperangkat alat sholat, dan tempat tidur (kasur dan
\end{abstract}


perlengkapannya) yang ada dalam pernikahan di Desa Buano Hatuputih mencerminkan suatu kebaikan yang harus dilakukan dan atau dilaksanakan oleh pihak baik laki-laki maupun perempuan setelah pernikahan itu selesai, karena hakikat dari pernikahan adalah untuk saling mengingatkatkan akan hubungan baik kepada Allah swt maupun kepada sesama manusia.

Kata kunci: Tradisi Pindah Marga, Pernikahan, Negeri Buano Hatuputih

\section{PENDAHULUAN}

Pernikahan bagi umat manusia adalah suatu yang sangat sakral dan mempunyai tujuan yang sakral pula dan tidak terlepas dari ketentuan-ketentuan yang ditetapkan syari'at agama. Pernikahan bukan semata-mata untuk memuaskan nafsu, melainkan meraih ketenangan, ketentraman dan sikap saling mengayomi di antara suami-istri dengan dilandasi cinta dan kasih sayang yang mendalam. (Mohammad Asnawi,2004:20). Memang tak dapat dipungkiri antara pria dan wanita sudah fitrahnya untuk saling mempunyai ketertarikan dan dari ketertarikan tersebut kemudian beranjak kepada niat suci pernikahan, proses ini mengandung dua aspek yaitu aspek biologis agar manusia itu berketurunan, dan aspek afeksional agar manusia merasa tenang dan tentram berdasarkan kasih sayang. Dengan cinta dan kasih sayang tidak hanya memungkinkan pasangan tersebut membentuk kehidupan keluarga yang damai dan bahagia, tetapi juga memberi kekuatan yang dibutuhkan untuk mengutamakan nilai-nilai kebudayaan yang lebih tinggi.

Perkawinan bagi sebagian besar orang adalah sebuah ikatan yang didasari oleh cinta kasih dan aturan sosial, budaya dan agama untuk membentuk sebuah keluarga. Oleh karena itu pada umumnya perkawinan dilakukan dengan mempertimbangkan aspek aspek tersebut, kesamaan latar belakang status sosial, budaya dan agama adalah pilihan yang paling banyak diambil oleh masyarakat. Namun bukan berarti perbedaan latar belakang aspek-aspek tersebut tidak akan menghasilkan perkawinan yang berhasil. Kini perkawinan beda budaya makin sering dijumpai di daerah perkotaan. Beberapa bahkan melakukan perkawinan dengan pasangan berbeda bangsa. Hal ini memunculkan generasi baru dengan pemahaman budaya yang berbeda dan beberapa mempunyai ciri fisik yang berbeda dengan orang tuanya. 
Al-Qur'an telah menerangkan sasaran tersebut, bahwa dalam pandangan Islam konsep perkawinan merupakan konsep cinta dan kasih sayang. Agar tujuan dan sasaran dalam pernikahan tercapai, dan mampu mewujudkan kehidupan rumah tangga yang sakinah, mawaddah, wa Rahmah. Maka kemudian, harus diperhatikan tentang syarat-syarat tertentunya, agar tujuan dari disyari'atkannya perkawinan dapat tercapai dan tidak menyalahi aturan yang telah ditetapkan Agama. Hal ini sebagaimana firman Allah swt:

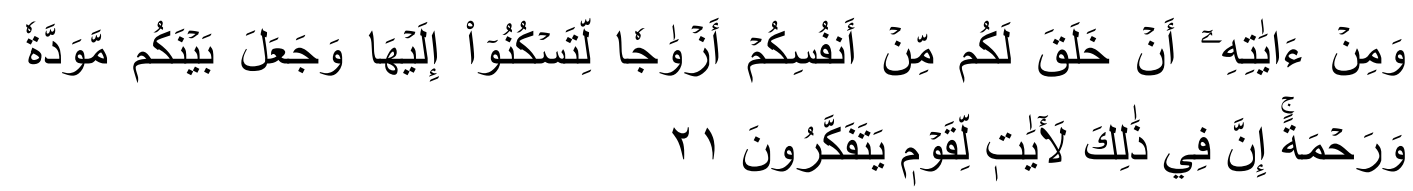

Terjemahnya: Dan di antara tanda-tanda kekuasaan-Nya ialah Dia menciptakan untukmu isteri-isteri dari jenismu sendiri, supaya kamu cenderung dan merasa tenteram kepadanya, dan dijadikan-Nya diantaramu rasa kasih dan sayang. Sesungguhnya pada yang demikian itu benar-benar terdapat tandatanda bagi kaum yang berfikir (QS. Ar-Rum, 30: 21) (Depertemen Agama RI, 2009:102).

Perkawinan itu diartikan sebagai perbuatan hukum yang mengikat antara seorang pria dan wanita (suami istri) yang mengandung nilai ibadah kepada Allah Swt di satu pihak dan pihak yang lainnya mengandung aspek keperdataan yang menimbulkan hak dan kewajiban antara suami istri. Islam dengan jelas pula menerangkan aturan perkawinan, namun aturan perkawinan yang berlaku di dalam masyarakat tidak terlepas dari pengaruh budaya dan lingkungan dimana masyarakat itu berada, dan yang paling dominan adalah dipengaruhi oleh adat istiadat dan budaya dimana masyarakat tersebut berdomisili.

Dalam hukum positif yang berlaku di Indonesia, bagi pasangan yang menikah dengan mengikuti aturan pencatatan perkawinan ini akan diberikan akta nikah. Keharusan pencatatan perkawinan ini juga dibarengi dengan berbagai aturan tambahan untuk menguatkannya, diantaranya untuk mengurus administrasi kependudukan, akte kelahiran anak, pendidikan, memasuki dunia kerja yang semuanya harus memakai akte nikah, termasuk juga dalam mengurus perceraian. Aturan-aturan ini dibuat agar pencatatan perkawinan memang dilaksanakan oleh setiap orang yang menikah, dan dilihat dari sisi kemaslahatannya, bagi negara 
adalah dalam rangka membuat administrasi negara dalam bidang keluarga yang teratur, sedangkan bagi masyarakat agar mereka mendapat jaminan dan kemudahan dalam setiap urusan adminsitrasi bernegara yang mengharuskan dilampirkannya surat nikah. Kehadiran UU No. 1 Tahun 1974 dan Kompilasi Hukum Islam (KHI) Tahun 1991, merupakan buah kerja keras ulama yang pro pembaruan hukum Islam dan tokoh-tokoh bangsa untuk memberikan aturan yang terukur dalam pelaksanaan sebuah perkawinan (Mas'udi, 2014:136-137).

Indonesia merupakan negara yang dikenal memiliki ratusan etnis yang tersebar. Jumlah yang besar ini masih ditambah dengan etnis pendatang, yang setelah lama berdiam di satu wilayah lalu melebur dengan penduduk lokal, makin memperkaya budaya yang ada di nusantara ini. Selain itu, sebagai negara yang memiliki ribuan pulau, peluang warganya untuk merantau atau berpindah dari satu daerah ke daerah lain, atau dari satu pulau ke pulau lain, menjadi salah satu latar belakang terjadinya pernikahan campuran antara dua budaya. Meskipun, di tengah keragaman budaya ini, masih banyak penganut paham konvensional yang hanya memperbolehkan keturunan mereka berhubungan dengan suku yang sama. Pernikahan dari dua suku yang berbeda memang bukan sesuatu yang baru, fenomena seperti ini sudah lama terjadi. Yang jadi masalah adalah, apabila calon pengantin berasal dari dua budaya yang sama sekali berbeda, musyawarah tentu harus dilakukan untuk mencapai kesepakatan antara dua budaya tersebut dan tentu saja untuk menghindari salah paham.

Perkawinan ideal ialah suatu bentuk perkawinan yang terjadi yang dikehendaki oleh suatu masyarakat. Suatu bentuk perkawinan yang terjadi berdasarkan suatu pertimbangan tertentu yang tidak menyimpang dari ketentuan aturan-aturan atau norma-norma yang berlaku di dalam masyarakat setempat. Sedangkan bagi masyarakat Negeri Buano Hatuputih, perkawinan yang dikehendaki atau perkawinan yang ideal adalah suatu perkawinan antara pemuda pemudi yang terjadi berdasarkan sama-sama saling mencinta, mempunyai tingkat pendidikan yang seimbang, kemudian memperoleh persetujuan orang tua dari kedua belah pihak dan antara pemuda dan pemudi mempunyai perbedaan umur paling sedikit lima tahun (umur laki-laki lebih tua dari pada umur perempuan). Selain perkawinan ideal, masyarakat Negeri Buano Hatuputih juga mengenal adat 
pembatasan jodoh, yaitu peraturan-peraturan yang melarang perkawinan diantara seseorang dengan orang tertentu berdasarkan garis keturunan seayah atau seibu karena dikhawatirkan akan terjadi kawin daudara, sehingga budaya dan adat tersebut dapat dijaga.

Adat adalah sebuah aturan yang lazim diikuti atau dilakukan sejak dahulu kala. Adat biasa juga disebut kearifan lokal yaitu semua bentuk pegetahuan, keyakinan, pemahaman atau wawasan serta adat kebiasaan atau etika yang menuntun perilaku manusia dalam kehidupan di dalam komunitas ekologis. Atau dapat juga berupa kebenaran yang telah mentradisi dalam suatu daerah (Keraf Gorys,2010:35). Istilah kearifan lokal (local wisdom) terdiri dari dua kata, yaitu kearifan yang berarti kebijaksanaan dan lokal yang berarti suatu tempat. Secara umum kearifan lokal dapat diartikan sebagai gagasan setempat yang bersifat bijaksana, penuh kearifan, bernilai baik dan terpelihara oleh masyarakat setempat (La Ode Taalami, 2010:26).

Kearifan lokal merupakan suatu pengetahuan lokal yang digunakan oleh suatu komunitas masyarakat lokal sehingga mereka dapat bertahan hidup dalam suatu lingkungan kolektif. Pada konteks ini, kearifan lokal dapat menyatu dengan sistem; kepercayaan, pandangan hidup, norma, nilai sosial (etika), pengetahuan, dan budaya yang diekspresikan dalam penerapan tradisi yang dianut oleh masyarakat secara turun-temurun. Implikasi teori-teori tersebut terhadap penelitian ini adalah kearifan lokal dipandang sebagai tradisi masyarakat yang terungkap pada masyarakat Negeri Buano Hatuputih dengan cerminan nilai-nilai luhur yang telah diterapkan secara turun-temurun.

Tradisi perkawinan menurut adat istiadat Negeri Buano Hatuputih antara lain mengandung nilai-nilai pendidikan Islam. Nilai tersebut dirumuskan dalam norma-norma yang akan menuntun masyarakat Negeri Buano Hatuputih dalam berfikir yang selanjutnya akan menentukan perilaku anggota komunitas bersangkutan. Demikian pula nilai pendidikan Islam tersebut akan dapat menentukan sikap-sikap masyarakat terhadap lingkungan kehidupannya yang juga menjurus kepada pola perilaku tertentu (Zainal Abidin Abubakar, 1993:143).

Dalam tradisi pada mulanya yang dilakukan peneliti diketahui bahwa di dalam masyarakat Negeri Buano Hatuputih ada sebuah tradisi yang dipraktekkan 
secara turun temurun. Adat tersebut juga berlaku bagi hampir seluruh masyarakat Negeri Buano Hatuputih yang ada di Maluku. Dalam perkembangannya, masyarakat Negeri Buano Hatuputih tidak hanya berdomisili di Negeri Buano saja akan tetapi telah menyebar ke berbagai wilayah Indonesia yang secara umum di Provinsi Maluku dan sekitarnya serta secara khusus di Negeri Buano Hatuputih Kecamatan Kepulauan Manipa Kabuapten Seram Bagian Barat. Di Negeri Buano Hatuputih khususnya masyarakat Negeri Buano Hatuputih, pindah marga dalam hal ini pihak laki-laki yang bersuku Buton menikah dengan wanita dari Negeri Buano Hatuputih harus mengikuti marga yang ada pada perempuan. Berdasarkan hasil wawancara dengan pemuka ada di negeri Buano Hatuputih dimana informan menuturkan bahwa:

Di Negeri Buano Hatuputih dalam sebuah prosesi pernikahan dimana pihak laki-laki dalam hal ini yang bukan dari beberapa marga asli (suku/orang Buano) yang hendak menikah dengan perempuan asli suku/orang Buano terkhusus Buano Hatuputih, maka laki-laki dari suku Buton tersebut harus pindah marga atau mengikuti marga perempuan seperti marga Lessi, dan marga Pacina yang ada di Negeri Buano Hatuputih dalam pernikahan yang merupakan salah satu syarat prosesi pernikah dalam adat Negeri Buano Hatuputih yang terjadi saat prosesi pernikahan dengan dimulai dari peminangan perempuan untuk dijadikan istri karena semua syarat yang akan diminta oleh pihak perempuan yang berkaitan dengan berbagai hal ihwal biaya pernikahan dibicarakan dalam pertemuan tersebut termasuk maskawin, dan lain sebagainya.

Memperjelas penuturan informan di atas, maka diperkuat dengan penuturan informan yang lainnya terkait dengan pindah marga setelah menikah antara laki-laki bersuku Buton dan perempuan bersuku Buano Hatuputi, sebagaimana diungkapkan oleh informan bahwa:

Salah satu ada pernikahan yang sudah terjali sejak dahulu kala dimana bila ada laki-laki (Buton) yang hendak menikah dengan perempuan Buano Hatuputih makan laki-laki tersebut setelah menikah harus (wajib) mengikuti atau memakai marga yang ada pada perempuan yang bermarga di Buano Hatuputih, sebagai wujud penghargaan laki-laki pendatang (tamu) kepada perempuan di Negeri Hatuputih yang sudah ada sejak dahulu kala, hal ini dilakukan karena sudah merupakan suatu kesepakatan adat pada masyarakat negeri Buano Hatuputih.

Dari hal tersebut maka, prosesi pernikahan secara adat akan disepakati untuk dilangsungkan dalam sebuah pernikahan secara sah baik dalam pandangan 
hukum Islam maupun hukum positif yang dibalut dengan adat dan tradisi termasuk memelihara adat perkawinan yang masih berlaku sampai sekarang sebagai salah satu bentuk atau syarat yang dalam sebuah pernikahan di Negeri Buano Hatuputih Kecamatan Kepulaua Manipa Kabupaten Seram Bagian Barat.

Berdasarkan pengamatan langsung yang dilakukan oleh penulis bahwa dalam perkawinan masyarakat Negeri Buano Hatuputih di Negeri Buano Hatuputih Kecamatan Kepulauan Manipa Kabupaten Seram Bagian Barat, terdapat unsur-unsur dalam pernikahan yang didalamnya terkandung bentuk adat istiadat berupa simbol yang memiliki arti yakni terdapatnya berbagai bentuk kesepakatan harta antara kedua belah pihak baik pihak keluarga perempuan maupun pihak keluarga laki-laki dalam melangsungkan pernikahan dalam keluarga yang banyak dipakai oleh masyarakat suku Negeri Buano Hatuputih secara umum dan khususnya Negeri Buano Hatuputih.

\section{METODE}

Metode penelitian yang digunakan dalam penelitian ini adalah deskriptif kualitatif yakni metode pendekatan yang memberikan gambaran tentang situasi dan kejadian secara sistematis dan faktual mengenai faktor-faktor, sifat-sifat hubungan antara fenomena yang dimiliki untuk melakukan akumulasi dasar-dasar, dimana pada umumnya metode ini diartikan secara luas yaitu bukan hanya memberikan gambaran terhadap fenomena, melainkan juga mengupayakan menerangkan hubunganhubungan, memperkuat prediksi, serta mendapatkan makna dan komplikasi dari permasalahan yang hendak dicapai (Lexy J Moleong, 2000:23).

\section{HASIL}

\section{Pelaksanaan Pernikahan dalam Adat Masyarakat Negeri Buano Hatuputih Kecamatan Kepulauan Manipa Kabupaten Seram Bagian Barat}

Pernikahan merupakan kebiasaan yang lazim dilaksanakan dalam masyarakat untuk mengatur masalah-masalah yang berhubungan dengan pernikahan. Pernikahan yang dilaksanakan pada setiap masyarakat 
mempunyai syarat-syarat tertentu sehingga pelaksanaannya tidak terlepas dari ketentuan adat yang berlaku dalam kehidupan masyarakat. Pada dasarnya ketentuan-ketentuan adat itu bagi kaum tua cenderung untuk memutlakkannya sedangkan untuk kaum muda sendiri menganggap ketentuan-ketentuan adat itu sangatlah membatasi hak mereka dalam menentukan sendiri kebahagiaan lewat pemilihan jodohnya.

Pernikahan di Negeri Buano Hatuputih erat kaitanya dengan pernikahan pada umumnya adalah sama, namun terdapat perbedaan sesuai ketetapan pada masing-masing adat pada suku yang ada di setiap daerah yang salah satunya yakni pernikahan di negeri Buano Hatuputih bila yang menikah adalah perempuan dari suku Buano dan laki-laki dari dari suku Buton secara umum. Berdasarkan hasil wawancara dengan pemuka ada di negeri Buano Hatuputih dimana informan menuturkan bahwa:

Di Negeri Buano Hatuputih dalam sebuah prosesi pernikahan dimana pihak laki-laki dalam hal ini yang bukan dari beberapa marga asli (suku/orang Buano) yang hendak menikah dengan perempuan asli suku/orang Buano terkhusus Buano Hatuputih, maka laki-laki dari suku Buton tersebut harus pindah marga atau mengikuti marga perempuan seperti marga Lessi, dan marga Pacina atau marga lainnya ada di Negeri Buano Hatuputih dalam pernikahan yang merupakan salah satu syarat prosesi pernikah dalam adat Negeri Buano Hatuputih yang terjadi saat prosesi pernikahan dengan dimulai dari peminangan perempuan untuk dijadikan istri karena semua syarat yang akan diminta oleh pihak perempuan yang berkaitan dengan berbagai hal inwal biaya pernikahan dibicarakan dalam pertemuan tersebut termasuk maskawin, dan lain sebagainya.

Memperjelas penuturan informan di atas, maka diperkuat dengan penuturan informan yang lainnya terkait dengan pindah marga laki-laki bersuku Buton dan perempuan bersuku Buano Hatuputi, sebagaimana diungkapkan oleh informan bahwa:

Salah satu ada pernikahan yang sudah terjali sejak dahulu kala dimana bila ada laki-laki (Buton) yang hendak menikah dengan perempuan Buano Hatuputih maka laki-laki tersebut setelah menikah harus (wajib) mengikuti atau memakai marga yang ada pada perempuan yang bermarga di Buano Hatuputih, sebagai 
wujud penghargaan laki-laki pendatang (tamu) kepada perempuan di Negeri Hatuputih yang sudah ada sejak dahulu kala, hal ini dilakukan karena sudah merupakan suatu kesepakatan adat pada masyarakat negeri Buano Hatuputih. Adapun syarat pindah marga bila laki-laki dari suku Buton tersebut ingin menikah dengan perempuan dari Buano Hatuputih yakni 1. Beragama Islam, 2. Siap bertanggungjawab lahir dan batin, 3. Bersedia (bila memungkinkan) tinggal di Negeri Buano Hatuputih, 4. Bersedia mengukuti kultur budaya dan adat di negeri Buano Hatuputih, 5. Bersedia menggunakan marga (dari pihak perempuan) yang ada di di Negeri Buano Hatuptih, 6. Membaca doa (doa selamatan) setelah proses pindah marga (bila bersedia) dilaksanakan. Olehnya itu, syarat yang dianggap sakral adalah syarat pada nomor 5 dimana bila syarat tersebut tidak dilakukan oleh laki-laki bersuku buton, maka akan muncul bala (musibah) berupa sakit yang berkepanjangan hal ini sudah terbukti kepada lelaki Buton yang yang sebelumnya tidak mengganti marga mengikuti marga perempuan (istri) yang dinikahi. Karena syarat tersebut merupakan syarat yang sudah disepakati oleh tokoh masyarakat, tokoh ada dan tokoh agama di negeri Buano Hatuputih. Selain itu, syarat tersebut karena merupakasn syarat yang sudah ada sejak turun temurun dari pendiri pertama desa atau negeri Buano Hatuputih.

Untuk memperjelas penuturan informan di atas, maka berikut peneliti menyajikan beberapa pernikahan masyarakat Negeri Buano Hatuputih dengan laki-laki suku Buton di Negeri Buano Hatuputih sebagai berikut:

Tabel 1. Warga desa yang telah pindah marga setelah menikah di Negeri Buano Hastuputih Kabupaten Seram Bagian Barat

\begin{tabular}{|c|l|l|c|l|}
\hline No & \multicolumn{1}{|c|}{$\begin{array}{c}\text { Nama dan } \\
\text { Marga } \\
\text { Sebelumnya }\end{array}$} & $\begin{array}{c}\text { Nama dan } \\
\text { Marga } \\
\text { Sekarang }\end{array}$ & $\begin{array}{c}\text { Tahun } \\
\text { Pernikahan }\end{array}$ & \multicolumn{1}{|c|}{ Keterangaan } \\
\hline 1 & Masrin Ode & Masrin Mahu & 2001 & Pindah ke Piru \\
\hline 2 & La Jumadi Wali & $\begin{array}{l}\text { Jumadi } \\
\text { Paihalu }\end{array}$ & 2004 & $\begin{array}{l}\text { Pindah ke } \\
\text { Waisarissa }\end{array}$ \\
\hline 3 & La Juma Siompu & Juma Lain & 2009 & Pindah ke Namlea \\
\hline 4 & La Jusri Wabula & Jusri Pacina & 2009 & Pindah ke Saluku \\
\hline 5 & Rais Ode & Rais Lesy & 2016 & $\begin{array}{l}\text { Menetap hingga } \\
\text { sekarang }\end{array}$ \\
\hline
\end{tabular}

Sumber data: Sekretaris Negeri Buano Hatuputih, 2020.

Berdasarkan dari tabel di atas, maka dapat diketahui bahwa terjadi proses pindah marga setelah menikah yang ada di negeri Buano Hatuputih sebanyak 5 orang laki-laki suku Buton, dana dari ke lima orang 
tersebut, han 1 orang yang menetap setelah menikah di Negeri Buano Hatuputih yakni Rais Lesy hingga sekarang sementara yang keemat lainnya telah pindah tempat tinggal ke tempat lain.

Saksi dalam pernikahan merupakan suatu keharusan sebagai bagian dari persyarat sahnya nikah baik secara hukum positif maupun hukum agama dan hukum adat yang berlaku. Oleh itu, untuk mengetahui para saksi yang langsung mengamati proses pindah marga dalam penirkahan di Negeri Buano Hatuputih disajikan dalam tabel sebagai berikut:

Tabel 2. Saksi pernikahan di Negeri Buano Hastuputih Kabupaten Seram Bagian Barat

\begin{tabular}{|c|l|l|l|c|}
\hline No & \multicolumn{1}{|c|}{$\begin{array}{c}\text { Nama Saksi } \\
\text { Pernikahan }\end{array}$} & $\begin{array}{c}\text { Nama dan } \\
\text { Marga } \\
\text { Sebelumnya }\end{array}$ & $\begin{array}{c}\text { Nama dan } \\
\text { Marga } \\
\text { Sekarang }\end{array}$ & $\begin{array}{c}\text { Tahun } \\
\text { Pernikahan }\end{array}$ \\
\hline 1 & $\begin{array}{l}\text { Salam Mahu } \\
\text { Ahmad Prawira }\end{array}$ & Masrin Ode & $\begin{array}{l}\text { Masrin } \\
\text { Mahu }\end{array}$ & 2002 \\
\hline 2 & $\begin{array}{l}\text { Muhammad Warang } \\
\text { Abdul Rajak Suku } \\
\text { Ali Lenauwe }\end{array}$ & $\begin{array}{l}\text { La Jumadi } \\
\text { Wali }\end{array}$ & $\begin{array}{l}\text { Jumadi } \\
\text { Paihalu }\end{array}$ & 2004 \\
\hline 3 & $\begin{array}{l}\text { Majid Lain } \\
\text { Ali Lenauwe }\end{array}$ & $\begin{array}{l}\text { La Juma } \\
\text { Siompu }\end{array}$ & Juma Lain & 2009 \\
\hline 4 & $\begin{array}{l}\text { Mutalib Pacina } \\
\text { Abdul Rajak Suku }\end{array}$ & $\begin{array}{l}\text { La Jusri } \\
\text { Wabula }\end{array}$ & Jusri Pacina & 2009 \\
\hline 5 & $\begin{array}{l}\text { Udin Suku } \\
\text { Majid Lain }\end{array}$ & Rais Ode & Rais Lesy & 2016 \\
\hline
\end{tabular}

Sumber data: Sekretaris Negeri Buano Hatuputih, 2020.

Berdasarkan data pada saksi yang telah disebutkan, maka dapat dikatakan bahwa dari hal tersebut maka, prosesi pernikahan secara adat akan disepakati untuk dilangsungkan dalam sebuah pernikahan secara sah baik dalam pandangan hukum Islam maupun hukum positif yang dibalut dengan adat termasuk memelihara adat perkawinan yang masih berlaku sampai sekarang sebagai salah satu bentuk atau syarat yang dalam sebuah pernikahan di Negeri Buano Hatuputih Kecamatan Kepulaua Manipa Kabupaten Seram Bagian Barat hingga sekarang.

2. Prosesi Pindah Marga dalam Adat Pernikahan Masyarakat Negeri Buano Hatuputih Kecamatan Kepulauan Manipa Kabupaten Seram Bagian Barat 
Berdasarkan pengamatan langsung yang dilakukan oleh penulis bahwa dalam perkawinan masyarakat Negeri Buano Hatuputih di Negeri Buano Hatuputih Kecamatan Kepulauan Manipa Kabupaten Seram Bagian Barat, terdapat unsur-unsur dalam pernikahan yang didalamnya terkandung bentuk adat istiadat berupa simbol yang memiliki arti yakni terdapatnya berbagai bentuk kesepakatan harta antara kedua belah pihak baik pihak keluarga perempuan maupun pihak keluarga laki-laki dalam melangsungkan pernikahan dalam keluarga yang banyak dipakai oleh masyarakat suku Negeri Buano Hatuputih secara umum dan khususnya Negeri Buano Hatuputih.

Bentuk penikahan adat pindah marga itu sendiri secara harfia berarti kumpulan, artinya suatu kumpulan saudara pada acara sebelum pernikahan dijalankan. Secara terperinci prosesi adat dalam peminangan di Negeri Buano Hatuputih yaitu:

1. Laki-laki (orang buton yang hendak menikah) melakukan lamaran/peminangan kepada perempuan (orang yang hendak dinikahi) baik secara langsung (laki-laki itu sendiri yang meminang) atau diwakilkan oleh orang tua (bapak) dari laki-laki tersebut kepada perempuan yang dituju.

2. Terjadi perdebatan tentang ketentuan terima atau tidak tentang peminangan/lamaran pernikahan tersebut.

3. Penentuan besarnya harta maskawin (pindah marga) yang disampaikan oleh pihak keluarga peremuan kepada pihak laki-laki berupa perhiasan (cincin, kalung, gelang, dan perhiasan lainnya yang terbuat dari emas), perlengkapan kecantikan wanita, (make up), tempat sirih (tembakau, sirih, pinang, kapur), tempat tidur (kasur, saprei, bantal dan guling, sarung dan perlengkapan lainnya) serta makanan dan sejeninsnya.

4. Pihak laki-laki dan perempuan menentukan kesiapan acara pernikahan yang meliputi tanggal, bulan dan tahun serta tempat dilangsungkannya pernikahan.

5. Pihak laki-laki berunding (antara terima dan atau tidak terima) terkait dengan besarnya harta yang diminta oleh pihak perempuan.

6. Pihak laki-laki melakukan guna berunding dikalangan keluarga laki-laki terkait dengan besarnya biaya yang harus disiapkan dalam pelaksanaan pernikahanan dengan cara mengumpulkan besarnya bantuan (taruhan uang) yang harus disiapkan oleh pihak keluarga lakilaki sehingga terjadinya proses pernikahan nantinya. 
Hal-hal di atas adalah cerminan dari adat istiadat masyarakat Negeri Buano Hatuputih yang harus dikerjakan dan dilalui oleh kedua belah pihak untuk menyatukan pendapat guna mencapai kesepakatan dalam melaksanakan rencana yang diinginkan. Akan tetapi, sampai tahapan ini belum dapat diambil Kesimpulan apakah keluarga laki-laki dan perempuan sudah sepakat mengenai syarat-syarat yang diajukan pihak keluarga perempuan. Mereka akan mengutarakan tentang mas kawin kepada pihak keluarga laki-laki melalui utusan keluarga tersebut, dan akan menjadi pertimbangan oleh pihak keluarga laki-laki apakah bersedia atau tidak bersedia untuk memenuhi mas kawin tersebut.

Dengan demikian, dalam pernikahan adat dengan yang berkaitan dengan ketentuan hukum adat tentang proses pernikahan yang terdapat di Negeri Buano Hatuputih dan dalam jangka waktu tertentu pula dengan sebuah simbol maskawin seperti cincin kawin, kalung, ataupun kain putih. Setalah upacara dilakasanakan berarti sejak saat itu acara pernikahan dan yang dilaksanakan oleh pihak keluarga laki-laki dengan peraturanperaturan atau saksi-saksi yang diterapkan sesuai dengan ada yang berlaku, dalam hal ini menyangkut seputar mas kawin yang harus disiapkan dan perlengkapan pernikahan yang dibicarakan oleh pihak keluarga laki-laki dengan pihak keluarga perempuan berdasarkan aturan hukum adat yang sudah menjadi ketetapan di Negeri Buano Hatuputih. Pelaksanaan pernikahan dengan simbol pernikahan tersebut pun juga dituturkan oleh bapak Tete Masahoy bahwa:

Pernikahan dengan salah satu adat yang sudah ditetapkan sejak Negeri Buano ada di pulaua Manipa merupakan tradisi guna menyatukan keluarga (pihak laki-laki) khususnya dari suku buton dan (pihak perempuan) dari suku Buano Hatuputih dengan ketentuan yakni adanya kebiasaan (adat) pindah marga dalam melangsungkan pernikahan hingga sekarang ini. Pindah marga bertujuan untuk menghormati keluarga perempuan dan memuliakan hubungan antara keluarga. Hal ini bukan merupakan suatu yang bersaifat keharusan sehingga tidak semata-mata merupakan kepentingan keluarga yang mengadakan perkawinan saja namun juga kepentingan dalam menjalani hubungan silaturahim antar warga masyarkat itu sendiri. 
Pelaksanaan pernikahan oleh masyarakat negeri Negeri Buano Hatuputih merupakan salah satu kegiatan dalam bentuk upaya memudahkan pihak keluarga yang melaksanakan pernikhan dengan berbagai bantuan baik biaya (uang) maupun tenaga (wujud kerja fisik) maupun dalam wujud peminajaman barang/benda sebagaimana yang dikemukakan oleh informan bahwa:

Dalam pernikahan di Buano Hatuputih ini khususnya orang Buton sudah menjadi kebiasaan untuk melakukan kegiatan dalam hal bantu-membantu sebagian angggota masyarakat yang melakukan hajatan dalam hal ini pernihakan karena ada rasa panggilan jiwa untuk saling menolong karena beta yakiin samua orang yang sudah berkeluarga pasti punya anak baik laki-laki maupun perempuan yang pastinya akan menikah juga nantinya, jadi, dengan katong saling membantu bagini agar harapannya besok-besok orang laeng juga bisa bantu katong, bantuan dalam bentuk apa saja selama katong bisa bantu.

Sementara menurut informan lainnya menyebutkan bahwa:

Pada kegiatan pernikahan yang berkaitan dengan adat pindah marga pada masyarakat Di Negeri Buano Hatuputih sini pelaksanaanya berdasarkan sudah ditentukan waktu pernikhannya berdasarkan kesepakatan kedua belah pihak (keluarga laki dan perempuan) dilakukan pada saat ada pernikahan tertentu saja yang waktunya tidak menentu yang dalam kegiatan ini terdapat didalamnya ada silaturahim sesama orang dan non buton yang berada disekitarnya, agar kegiatan pernikahan tersebut biasanya menjadi ramai sekali, meriah, dan pastinya mengharapkan berkah dari Allah swt.

Sementara pernikahan dengan dalam hal pindah marga merupakan bentuk interaksi yang tergalang di tengah masyarakat dan bertujuan untuk menjalin silaturahim dalam rangka mendekatkan diri kepada Allah swt dengan cara melakukan upacara atau tradisi yakni berkumpul dan melakukan silaturahim antar sesama masyarakat dalam satu kegiatan, merupakan wujud dari kegiatan yang bersifat sosial religius di tengah masyarakat. Hal ini sebagaimana disapaikan oleh informan, bahwa:

Bentuk pernikahan dengan adat pindah marga ini adalah bentuk ajang silaturahin antar manusia yang satu dengan yang lainnya dengan jalan silaturahin yang terkandung didalammnya kegitan 
religius yakni pembacaan doa agar acara pernikahan tersebut dapat terlaksana dengan baik sesuai dengan niat dari yang melakukan hajat tersebut dan karna berdoa apabila dilakukan oleh banyak orang akan mendapatkan berkah yang banyak karna bersifat positif.

Hal yang sama juga disampaikan oleh informan lainnya yang menuturkan bahwa:

Kebudayaan masyarakat Negeri Buano Hatuputih terhadap pernikahan dengan pendekatan adat pindah marga mengandung nilai-nilai keagamaan dan nilai-nilai kesopanan seperti membaca ayat-ayat suci Al-Qur'an, tingkah laku berbicara dengan orang yang lebih dewasa di depan forum adat sehingga terjalin kerukunan di masyarakat. Antara budaya dan agama dalam masyarakat Negeri Buano Hatuputih terwujud pada pelaksanaannya baik di masjid maupun di rumah mempelai (baik laki-laki maupun perempuan) sebagai salah satu bentuk perwujudan dari agama sehingga adat pernikahan tersebut berjalan sesuai dengan anjuran agama yang di anut oleh masyarakat Negeri Buano Hatuputih tersebut.

Dengan demikian, maka dapat dikatakan bhawa perkawinan dipandang dari sudut kebudayaan merupakan pengatur kelakuan manusia yang bersangkut paut dengan kehidupan seks dalam masyarakat bahwa seorang laki-laki tidak dapat berhubungan intim dengan sembarang wanita tetapi hanya satu wanita yakni istrinya dalam bermasyarakat. Selain sebagai pengatur kelakuan seks perkawinanan mempunyai fungsi lain dalam kehidupan masyarakat dan kebudayaan yakni terjalinan interkasi sosial antar masyarakat sebagaimana pernikahan adat yang terjadi di Negeri Buano Hatuputih khususnya pernikahan.

\section{PEMBAHASAN}

Pernikahan adalah suatu peristiwa yang sangat penting dalam penghidupan masyarakat, sebab perkawinan tidak hanya menyangkut pria dan wanita bakal mempelai saja, melainkan juga orang tua kedua belah pihak, saudara-saudaranya bahkan keluarga mereka masing-masing. Perkawinan itu merupakan suatu kewajiban manusia sebagai mahluk Tuhan di muka bumi ini. Namun dalam proses pelaksanaannya, perkawinan itu harus sesuai dengan ketentuan hukum, adat dan agama yang telah ditetapkan. Dalam ketentuan adat misalnya, perkawina itu tidak 
boleh melanggar aturan adat yang berlaku dalam kehidupan masyarakat penganutnya, jika hal ini terjadi maka sipelanggar akan dikenakn sanksi adat.

Berbicara masalah perkawinan yang terkadang menjadi persoalan adalah tentang upacara resepsinya. Sebagaimana kita ketahui, bahwa perkawinan ini terjadi antara dua sisi kehidupan yang sangat berbeda baik dari jenis kelamin sampai kepada kepribadian. Dari kepribadian yang berbeda inilah semua itu dimulai untuk disatukan dalam satu kendali kebersamaan. Memang hal ini tidaklah semudah yang diucapkan. Setiap hal apapun tidaklah mungkin langsung terjadi sedemikian rupa, tetapi diawali dengan proses yang memakan waktu cukup lama, apalagi mengenai masalah pernikahan. Pelaksaan adat merupakan aturan, kebiasaan-kebiasaan yang tumbuh dan terbentuk dari suatu masyarakat atau daerah yang dianggap memiliki nilai dan dijunjung serta dipatuhi masyarakat pendukungnya (Hari Poerwanto, 2000:24). Adat merupakan norma yang tidak tertulis, namun sangat kuat mengikat sehingga anggotaanggota masyarakat yang melanggar adat istiadat akan menderita, karena sanksi keras yang kadang-kadang secara tidak langsung dikenakan.

Sebagaimana adat dalam pernikahan masyarakat lain, maka adat dalam pernikahan yang terdapat pada masyarakat Negeri Buano Hatuputih merupakan bentuk adat yang telah melekat dan berakar karena sejak dahulukala yang dilaksanakan dalam keadaan tertentu (tidak terbat pada tanggal, hari, bulan dan tahun). Dalam upacara adat perkawinan di Negeri Buano Hatuputih merupakan salah satu kebudayaan masyarakat yang sekarang ini masih belum juga usang untuk dibicarakan di kalangan para sejarawan. Secara teoritis upacara adat perkawinan masyarakat Negeri Buano Hatuputih adalah pranata yang dilaksanakan atas dasar budaya dan aturan-aturan adat setempat. Adapun jodoh yang ditentukan oleh Allah swt diatur oleh keluarga besar, dengan mempertimpangkan bibit, bebet, bobot yang merupakan pertimbangan atas pertimbangan sosial, karir, dan ekonomi seseorang yang lazim menjadi istrinya. Oleh 
sebab itu, perkawinan merupakan tugas suci (sakral) bagi manusia untuk mengembangkan keturunan yang baik dan berguna bagi masyarakat luas.

Dalam kehidupan manusia, pernikahan bukan saja sekedar istemewa tetapi

juga sangat sakral dan erat kaitannya dengan agama, bahkan menikah merupakan hal yang sangat diidam-idamkan oleh setiap orang. Karena itu, oleh kebanyakan orang upacara pernikahan selalu dikemas dengan berbagai corak dan ragam, baik itu secara adat dan budaya leluhurnya ataupun dengan cara modern yang tidak mengurangi rasa suka citanya serta nilai-nilai adat istiadat leluhur. Bertujuan untuk mengabadikan momen yang sangat penting dan sakral itu. Begitu juga dengan masyarakat Negeri Buano Hatuputih khususnya, budaya dan adat istiadat sangat erat kaitannya dengan kehidupan mereka sehari-hari, apalagi halhal tersebut ada kaitannya dengan upacara resmi. Tidak heran jika dalam melaksanakan upacara pernikahan di Negeri Buano Hatuputih akan banyak kita temukan upacara-upacara adat.

Dasar hukum pernikahan pada dasarnya adalah jaiz (diperbolehkan). Namun dari segi diminta dikerjakan atau tidak, maka menurut para ahli dalam fiqh bergantung pada keadaan masing-masing orang:

a. Wajib. Menurut kebanyakan para ulama fiqh, hukum pernikahan adalah wajib, jika seseorang yakin akan jatuh kedalam perzinaan seandainya tidak menikah, sedangkan ia mampu untuk memberikan nafkah kepada isterinya berupa mahar dan nafkah batin serta hak-hak pernikahan lainnya. la juga tidak mampu menjaga dirinya untuk terjatuh kedalam perbuatan hina dengan cara berpuasa dan lainnya.

b. Haram. Nikah diharamkan jika seseorang yakin akan menzalimi dan membahayakan istrinya jika menihak, seperti dalam keadaan tidak mampu untuk memenuhi kebutuhan pernikahan, atau tidak bisa berbuat adil diantara istri-istrinya. Karena segala sesuat yang menyebabkan terjerumus kedalam keharaman hukumnya juga haram. 
c. Makruh. Pernikahan dimakruhkan jika seseorang khawatir terjatuh pada dosa dan mara bahaya. Menurut para ulama syafi'i, menikah makruh hukumnya bagi orang yang memiliki kelemahan, seperti tua renta, penyakit abadi, kesusahan yang berkepanjangan.

d. Sunah. Menurut jumhur ulama selain imam syafi'i, nikah disunahkan jika seseorang dalam kondisi stabil.

Perkawinan dalam Islam adalah akad yang menghalalkan hubungan antara laki-laki dan perempuan yang bukan muhrim untuk memenuhi tujuan hidup berumah tangga sebagai suami isteri yang sah dengan memenuhi syarat dan rukun yang telah ditentukan oleh syara. Firman Allah di dalam Al-Qur'an yang mengatur masalah perkawinan guna melangsungkan kehidupan jenis masing-masing.

Di samping itu, pelaksanaan pernikahan mengikuti adat salah satunya didorong oleh faktor norma dan nilai sosial secara teoritis disebut folkways. Walaupun dalam folkways, pernikahan yang dilangsungkan akan tetap berada dalam kerangka seperti yang sudah dipraktekkan oleh orang terdahulu. Ini semata-mata karena selalu berulang dan dianggap standar. Sehingga secara normatif tetap akan dijalankan. Sanksi sosial yang datang secara tidak formal berupa gunjingan, olok-olok dan pembicaraan masyarakat menjadi faktor sehingga pelaksanaan pernikahan dengan berpegang pada tradisi selalu lebih diutamakan (Soetandyo, 2004:48).

Dari uraian yang telah dikemukan oleh beberapa sumber diatas bila dicermati, maka bentuk pernihakan yang yang dilaksanakan di Negeri Buano Hatuputih merupakan suatu bentuk atau unsur yang sangat baik bila diterapkan karena terdapat unsur silaturahim antar warga yang terdorong untuk saling membantu dalam memudahkan urusan yang berkaitan dengan harta atau biaya pernikahan yang harus dipikul atau ditanggung oleh pihak keluarga laki-laki, kartena dengan adanya pernikahan tersebut memungkinkan sutu keringanan beban yang terjadi pada keluarga laki-laki dalam melangsungkan acara peminangan sampai dengan acara penikahan nantinya. Karena bila ditelusuri secaram 
mendalam bahwa pernikhana dengan adat pindah marga sangat baik karena mengandung unsur kemudahan dalam menjalankan sunnah nabi yakni melaksanakan pernikahan. Dalam hidup berkelompok itu terjadilah interaksi antar manusia. Interaksi yang dilakukan pasti ada kepentingannya, sehingga bertemulah dua atau lebih kepentingan. Pertemuan kepentingan tersebut disebut kontak. Menurut Surojo Wignjodipuro, ada dua macam kontak (Hazairin, 1993:52), yaitu:

1. Kontak yang menyenangkan, yaitu jika kepentingan-kepentingan yang bertemu saling memenuhi.

2. Kontak yang tidak menyenangkan, yaitu jika kepentingan-kepentingan yang bertemu bersaingan atau berlawanan.

Mengingat banyaknya kepentingan, terlebih kepentingan antar pribadi, tidak mustahil terjadi konflik antar sesama manusia, karena kepentingannya saling bertentangan. Agar kepentingan pribadi tidak terganggu dan setiap orang merasa aman, maka setiap bentuk gangguan terhadap kepentingan harus dicegah. Manusia selalu berusaha agar tatanan masyarakat dalam keadaan tertib, aman, dan damai, yang menjamin kelangsungan hidupnya.

Dari sudut pandang sosiologis, kebudayaan di lihat sebagai pola kelakuan warga masyarakat yang bersangkutan. Cara berpikir dan bertindak, bahkan cara mengembangkan perasaan tidak dilakukan orang tanpa patokan, tetapi mengikuti satu pola tertentu, suatu pola yang sudah dikenal dan disepakati bersama dan hendak dilestarikan eksistensinya. Anggota baru yang masuk ke dalam satuan budaya itu karena kelahiran atau sebagai pendatang, dan belum mengenal pola tingkah laku masyarakat itu, diwajibkan mengenal dan mempelajari serta membiasakan diri untuk berbicara dan bertindak sesuai dengan kebudayaan setempat (D Hendropuspito, 1999:149).

Perkawinan ideal ialah suatu bentuk perkawinan yang terjadi dan dikehendaki oleh masyarakat. Suatu bentuk perkawinan yang terjadi berdasarkan suatu pertimbangan tertentu, tidak menyimpang dari ketentuan aturan-aturan atau norma-norma yang berlaku dalam 
masyarakat setempat. Perkawinan biasanya diartikan sebagai ikatan lahir batin antara pria dan wanita sebagai suami isteri, dengan tujuan membentuk suatu keluarga bahagia dan kekal berdasarkan Ketuhanan Yang Maha Esa. Dari pasangan demi pasangan itulah selanjutnya terlahir bayi-bayi pelanjut keturunan yang pada akhirnya mengisi dan mengubah warna kehidupan di dunia ini. Oleh karena itu, bagi masyarakat Jawa khususnya, makna sebuah perkawinan menjadi sangat penting. Selain harus jelas bibit, bebet,

dan bobot bagi si calon pasangan, berbagai perhitungan ritual lain harus pula diperhitungkan agar perkawinan itu bisa lestari, bahagia dan dimurahkan rejekinya oleh Tuhan Yang Maha Kuasa, dan pada akhirnya melahirkan anak-anak yang cerdas, patuh kepada kedua orangtuanya, serta taat beribadah (Artati Agoes,2001).

Sejalan dengan uraian tersebut, (Geertz,2000:45) mengemukakan bahwa benda-benda yang ditampilkan dalam upacara adalah sistem simbol yang berfungsi sebagai wahana pengintegrasian antara etos dan pandangan hidup merupakan konsepsi warga masyarakat yang menyangkut dirinya, masyarakatnya, alam dan lingkungan sekitarnya. Sebagai salah satu produk budaya, simbol benda-benda yang digunakan dalam adat pernikahan merupakan bentuk pengungkapan yang pada prinsipnya bertujuan untuk mengkomunikasikan pikiran dan perasaan masyarakat yang tumbuh dan bekembang dari waktu ke waktu. Salah satu bentuk pengungkapan simbol sebagai produk budaya adalah folklor yaitu yang berbentuk ungkapan tradisional (Moeryati Soedibyo, 2001:16). Folklor adalah sebagian kebudayaan suatu kolektif yang tersebar dan diwariskan secara turun temurun, diantara kolektif macam apa saja secara tradisional dalam versi yang berbeda.

Khususnya pada masyarakat Buton, yang memiliki berbagai tradisi budaya, mulai dari upacara adat kelahiran, sunatan, pernikahan, kematian dan sebagainya. Hal tersebut, sebenarnya diyakini oleh masyarakat Sunda sebagai kewajiban yang memiliki arti tertentu. Artinya, upacara adat tersebut, merupakan respon masyarakat Sunda untuk menyambut 
tahapan kehidupan manusia. Hal ini, merupakan efek dari pola pikir mereka yang meyakini bahwa manusia pada hakikatnya, tidak hidup sendiri di dunia ini, mereka ditemani oleh arwah nenek moyang. Dengan demikian, arwah nenek moyang mereka dianggap sebagai roh kebaikan yang akan membuat kehidupan manusia menjadi lebih bahagia. Oleh karena itu, pada setiap tahapan upacara adat, masyarakat Buton biasanya menggunakan simbol sebagai media atau lambang.

Dengan demikian, maka nilai-nilai budaya yang terdapat pada masyarakat Negeri Buano Hatuputih merupakan sebagai pedoman yang memberi arah dan orientasi terhadap hidup masyarakat yang umum dan sebaliknya, norma yang berupa aturan-aturan untuk bertindak bersifat khusus, sedangkan perumusannya biasanya bersifat amat terperinci, jelas, tegas, dan tak meragukan seperti halnya di Negeri Buano Hatuputih. Hal itu memang seharusnya demikian, sebab kalau bersifat umum dan ruang lingkup yang cukup luas, maka norma tersebut tak dapat mengatur tindakan masyarakat dan membingungkan masyarakat yang bersangkutan mengenai prosedur serta tata cara bagaimanakah suatu tindakan itu, sebaiknya dilaksanakan norma-norma dalam rangka suatu pranata dan sub-sub pranatanya yang mempunyai arti saling berkaitan satu dengan yang lain, dan karena itu juga merupakan suatu sistem yang terintegrasi.

\section{KESIMPULAN}

Berdasarkan hasil temuan dalam pembahasan terkait dengan Etnografi: Tradisi Pindah Marga Dalam Pernihakan Di Negeri Buano Hatuputih Kecamatan Kepulauan Manipa Kabupaten Seram Bagian Barat, maka dapat disimpulkan bahwa prosesi pernikahan dalam hal ini pernikahan yagn terjadi di Negeri Buano Hatuputih merupakan proses pernikahan secara islami dan sah secara hukum positif namun proses tersebut dipertegas dengan ketentuan dalam hal ini adalah masyarakat (laki-laki) suku Buton yang menikah dengan masyarakat (perempuan) dari Negeri Buano Hatuputih harus mengikuti marga perempuan suku Buano 
Hatuputi merupakan karena sudah berlangusng secara turun temurun dan berdasarkan kultur adat dan budaya yang sudah terjalin dengan tidak ada unsur paksanaan karena hal ini sudah berlaku dan bersifat khusus, sedangkan proses penikahannya bersifat umum sebagaiman diatur dalam syariat Islam yang dilaksanakan di Negeri Buano Hatuputih.

\section{DAFTAR PUSTAKA}

[1] Agoes, Artati, 2001. Kiat Sukses Menyelenggarakan Pesta Pernikahan Adat Jawa; Gaya Surakarta dan Yogyakarta, Jakarta: Gramedia Pustaka Utama.

[2] Ali, H. Zainuddin, 2006. Sosiologi Hukum, Jakarta: Sinar Grafika.

[3] Almath, Muhammad Almath, 1994. 1100 Hadist Terpilih, Sinar Ajaran Muhammad, Jakarta: Gema Insani Press.

[4] Asnawi, Mohammad, 2004. Nikah Dalam Perbincangan dan Perdebatan, Yogyakarta: Darussalam.

[5] Burke, Peter, 2001. Sejarah dan Teori Sosial, Jakarta: Yayasan Obor Indonesia.

[6] Departemen Agama RI. Al-Qur'an dan Terjemahannya, PT. Sygma Examedia Arkanleema: Bandung, 2009.

[7] Geettz, Cliffor, 2000. Kebudayaan dan Lingkungan dalam Perspektif Antropologi, Yogyakarta: Pustaka Pelajar.

[8] Gorys, Keraf, 2010. Linguistik Bandingan Historis. Jakarta: Gramedia Pustaka Utama.

[9] Hadikusuma, Hilman, 2000. Hukum Pernikahan Indonesia, Menurut Perundangan, Hukum Adat, Hukum Agama, Bandung: Mandar Maju.

[10] Hazairin, dalam Ludis, 2006. Peranan Hukum Adat dan Pengaruhnya dalam Penyelenggaraan Pemerintahan Desa", Pontianak: Skripsi Sarjana Muda APDN.

[11] Herusatoto, Budiono, 2000. Simbolisme Dalam Budaya. Yogyakarta: Hanindita Graha Widia.

[12] Koentjaraningrat, 1992. Beberapa Pokok Antropologi Sosial, Jakarta: Dian Rakyat.

[13] Koentjaraningrat, 2005. Pengatar Antropologi Jilid II, Cet. III; Jakarta: Rineka Cipta.

[14] Miles, Matthew dan A. Michael Huberman, 2000. Analisa data Kualitatif: Buku Sumber Tentang Metode-Metode Baru. Cet. I; Jakarta: UI Press.

[15] Moleong, Lexy J., 2000. Metode Penelitian Kualitatif, Bandung: PT. Remaja Rosdakarya.

[16] OC, D. Hendropuspito, 1999. Sosiologi Sistematik, Jakarta: Kanisius.

[17] Pals, Daniel L., 1996. Pals, Seven Theories of Religion, dari Animisme, Materialisme Hingga Antropologi Budaya. Yogyakarta: Qalam

[18] Poerwadarminta, W.J.S, 2002. Кати Umum Bahasa Indonesia, Jakarta: Balai Pustaka.

[19] Poerwanto, Hari, 2000. Kebudayaan dan Lingkungan dalam Perspektif Antropologi, Yogyakarta: Pustaka Pelajar. 
[20] Purwadi, 2005. Upacara Tradisional, Menggali Untaian Kearifan Lokal, Yogyakarta: Pustaka Pelajar.

[21] Shiddiqy, Hasbi As 2000. Mutiara Hadits, Cet. I; Jilid VIII; Jakarta: Bulan Bintang.

[22] Soedibyo, Moeryati, 2001. Pengantin Indonesia. Jakarta: Tamboer Press.

[23] Soekanto, Soerjono, 1992. Intisari Hukum Keluarga, Bandung, Sitra Aditya Bakti.

[24] Soemitro, Ronny Hanitijo, 2000. Metodologi Penelitian Hukum, Jurumetri dan Sosial, Jakarta: Ghalia Indonesia.

[25] Sukmadinata, Nana Saodih, 2005. Metode Penelitian Kualitatif. Bandung: PT. Remaja Rosdakarya.

[26] Syaifaut, Syaikh M., 1997. Islam sebagai Aqidah dan Syariat, Jakarta: Bulan Bintang.

[27] Syarifuddin, Amir, 2006. Hukum Pernikahan Islam di Indonesia, Antara Fiqh Munakahat dan Undang-Undang Pernikahan, Jakarta: UI Press.

[28] Taalami, La Ode, 2010. Kearifan Lokal dalam Kebudayaan Suku Bangsa di Sulawesi Tenggara. Kendari: Kebudayaan dan Parawisata Sultra.

[29] Wignjosoebroto, Soetandyo, 2004. Norma dan Nilai Sosial, dalam Sosiologi Teks Pengantar dan Terapan, Cet. IV; Ed. III, Jakarta: Prenada Media Group. 